\title{
Virulensi Isolat Rice tungro virus dari Beberapa Daerah Endemis Tungro di Indonesia
}

\author{
Virulence of Rice tungro virus Isolates from \\ Several Endemic Areas in Indonesia
}

\author{
Suprihanto ${ }^{1 *}$, Endang Nurhayati ${ }^{2}$, Jumanto Harjosudarmo ${ }^{3}$ \\ ${ }^{1}$ Balai Besar Penelitian Tanaman Padi, Sukamandi 41256 \\ ${ }^{2}$ Institut Pertanian Bogor, Bogor 16680 \\ ${ }^{3}$ Balai Besar Penelitian Bioteknologi dan Sumberdaya Genetika Pertanian, Bogor 16111
}

\begin{abstract}
ABSTRAK
Penelitian dilakukan untuk membedakan virulensi isolat Rice tungro virus (RTV) dari beberapa daerah endemis penyakit tungro di Indonesia berdasarkan reaksinya pada tanaman inang diferensial. Delapan isolat RTV dikumpulkan dari beberapa daerah endemis penyakit tungro di Indonesia, yaitu Bali (Denpasar), Kalimantan Selatan (Tanah Laut), Sulawesi Selatan (Lanrang), Jawa Barat (Subang dan Bogor), Jawa Tengah (Solo), Jawa Timur (Jember), dan Nusa Tenggara Barat (Mataram). Semua isolat dipelihara pada kultivar padi TN1 di rumah kaca melalui penularan serangga vektor Nephotettix virescens, selanjutnya masing-masing isolat ditularkan pada kultivar padi diferensial FK135 dan TN1. Empat minggu setelah inokulasi pada kultivar padi diferensial diamati gejala yang muncul dan infektifitas masing-masing isolat RTV. Tingkat virulensi isolat RTV dari beberapa daerah endemis penyakit tungro di Indonesia dapat dikelompokkan menjadi 3 tingkat. Virulensi paling tinggi ialah isolat RTV dari Jawa Barat; tingkat virulensi moderat ialah isolat RTV dari Jawa Timur, Kalimantan Selatan, Sulawesi Selatan dan Nusa Tenggara Barat; tingkat virulensi rendah ditunjukkan oleh isolat RTV dari Bali dan Jawa Tengah.
\end{abstract}

Kata kunci: kultivar diferensial, Nephotettix virescens, padi, penyakit tungro

\begin{abstract}
The research was conducted to distinguish the virulence of Rice tungro virus (RTV) isolates from several tungro disease endemic areas in Indonesia based on their response in differential cultivars of rice. Eight isolates of RTV were collected from several tungro endemic regions in Indonesia i.e. Bali (Denpasar), South Kalimantan (Tanah Laut), South Sulawesi (Lanrang), West Java (Subang and Bogor), Central Java (Solo), East Java (Jember), and West Nusa Tenggara (Mataram). The isolates were maintained on TN1 rice cultivar in greenhouse by successive transfers via Nephotettix virescens. Each isolate was subsequently passed on to FK135 and TN1 rice cultivars. Four week after inoculation, plants responses were observed to compare their symptom and infectivity on the differential cultivars. The results showed that the level of virulence of RTV isolate from tungro disease endemic areas in Indonesia can be classified into 3 levels. The highest virulence were RTV isolates from West Jawa, the moderate level of virulence were RTV isolates from East Java, South Kalimantan, South Sulawesi, and West Nusa Tenggara, the low level of virulence were RTV isolates from Bali and Central Java.
\end{abstract}

Key words: differential cultivar, Nephotettix virescens, rice, tungro diseases

*Alamat penulis koresponsdensi: Balai Besar Penelitian Tanaman Padi, Jalan Raya No. 9 Sukamandi Ciasem Subang 41256, Tel: 0260-520157 Faks: 0260-520158, Surel: s_prihant@yahoo.com 


\section{PENDAHULUAN}

Penyakit tungro pada tanaman padi merupakan salah satu kendala untuk mencapai stabilitas produksi. Penyakit tungro disebabkan oleh infeksi dua virus yang berbeda, yaitu Tungro bacilliform badnavirus (RTBV) dan Rice tungro spherical waikavirus (RTSV). Partikel RTSV dapat ditularkan oleh Nephotettix virescens, tetapi penularan RTBV bergantung pada partikel RTSV. Gejala pada padi terutama disebabkan oleh partikel RTBV dan lebih diperkuat oleh partikel RTSV. Secara umum, tanaman padi terinfeksi hanya oleh RTSV tidak menampakkan gejala khas tungro melainkan kerdil sangat ringan, sementara infeksi oleh RTBV saja menampakkan gejala tungro ringan. Apabila tanaman padi terinfeksi oleh RTBV dan RTSV secara bersama-sama, akan menunjukkan gejala tungro yang parah, termasuk kerdil, perubahan warna daun menjadi kuning atau kuning-oranye, dan penurunan jumlah anakan (Hibino et al. 1978).

Daerah sebaran utama penyakit tungro adalah di Provinsi Jawa Barat, Jawa Timur, Jawa Tengah, Bali, Sulawesi Selatan, Lampung, Banten, Sulawesi Tengah, Sumatera Utara, Kalimantan Selatan, dan Irian Jaya (Raga 2008). Widiarta dan Daradjat (2000) melaporkan bahwa daerah endemis penyakit tungro di sentra produksi padi di Indonesia antara lain ialah Gianyar (Bali), Tanggul (Jawa Timur), Klaten (Jawa Tengah), Tanjungsiang (Jawa Barat), Mataram (Nusa Tenggara Barat); sementara sebaran penyakit tungro di sentra produksi padi Indonesia Timur dengan intensitas penyakit yang tinggi meliputi Kabupaten Mamuju (Sulawesi Barat), Parigi (Sulawesi Tengah), Lanrang (Sulawesi Selatan), dan Merauke (Papua). Penyakit tungro di Sulawesi Selatan berhasil dikendalikan dengan cara memadukan waktu tanam yang tepat dan pergiliran varietas tahan (Sama et al. 1991). Di Sulawesi Selatan, populasi wereng hijau mencapai puncak tertinggi pada saat mendekati akhir musim hujan dan puncak kedua yang lebih rendah terjadi pada akhir musim kemarau. Waktu yang optimum untuk tanam padi di pesisir timur
(Maros) untuk menurunkan risiko serangan tungro ialah pada bulan Desember-Januari pada musim hujan dan Juni-Juli pada musim kemarau. Di daerah pesisir Barat (Lanrang), waktu tanam optimum direkomendasikan pada bulan April-Mei, sedangkan di daerah antara pesisir timur dan barat waktu tanam optimum pada bulan Desember atau Januari. Dengan rekomendasi waktu tanam ini, saat tanaman mencapai stadium bunting (umur 6070 hari) terjadi sebelum populasi wereng hijau tinggi, atau dengan kata lain pada saat populasi wereng hijau tinggi tanaman sudah lebih tahan terhadap infeksi tungro. Selain waktu tanam yang tepat, juga dilakukan pergiliran varietas tahan.

Informasi tentang virulensi RTV dapat digunakan sebagai dasar pewilayahan varietas tahan tungro (Burhanuddin et al. 2006). Penelitian untuk mengetahui variasi virulensi virus tungro terutama dari daerah endemis tungro di Indonesia sangat diperlukan untuk keperluan tersebut.

Tingkat virulensi virus tungro dapat dibedakan dengan menggunakan kultivar diferensial. Cabauatan et al. (1995) menemukan empat galur virus tungro di Filipina, yaitu galur L, G1, G2, dan Ic dengan membedakannya pada kultivar padi FK135 dan TN1. Berdasarkan pada hasil uji kultivar padi tahan tungro, Widiarta et al. (2008) melaporkan ada 4 varian virus tungro di Indonesia, yaitu varian 033 ditemukan di Jawa Barat dan Yogyakarta, varian 013, 003, dan 043 berturut-turut ditemukan dari Jawa Tengah, Jawa Timur, dan Bali. Dilaporkan pula bahwa perubahan keefektifan inokulum tungro dapat terjadi dalam satu musim tanam, bahkan dalam sekali siklus inokulasi.

Penelitian ini dilakukan untuk menetapkan tingkat virulensi RTV yang terdapat pada berbagai daerah endemis penyakit tungro di Indonesia menggunakan tanaman diferensial.

\section{BAHAN DAN METODE}

\section{Penyiapan Isolat Virus}

Isolat virus dikoleksi dari beberapa daerah endemis tungro di Indonesia, yaitu 
Bali (Denpasar), Kalimantan Selatan (Tanah Laut), Sulawesi Selatan (Lanrang), Jawa Barat (Subang dan Bogor), Jawa Tengah (Solo), Jawa Timur (Jember), dan Nusa Tenggara Barat (Mataram). Isolat virus dari lapangan tersebut selanjutnya disebut RTV karena tidak dibedakan antara RTSV dan RTBV. Isolat RTV tersebut dipelihara pada tanaman padi TN1 dengan cara ditularkan oleh $N$. virescens mengikuti prosedur Azzam et al. (2000). Wereng hijau diletakkan pada tanaman padi sakit selama 4 hari untuk akuisisi, selanjutnya tanaman padi TN1 sehat berumur 45 hari dalam pot (2 tanaman per pot) dimasukkan dalam kurungan selama 4 jam dengan wereng hijau viruliferus (3 wereng per tanaman). Perkembangan gejala diamati selama 2 sampai 3 minggu, selanjutnya tanaman padi terinfeksi digunakan sebagai sumber inokulum.

Uji Virulensi pada Kultivar Padi Diferensial

Kultivar padi diferensial yang digunakan ialah TN1 dan FK135. Kultivar padi TN1 diperoleh dari Balai Besar Penelitian Tanaman Padi Sukamandi dan kultivar padi FK135 diperoleh dari International Rice GeneBank, International Rice Research Institute (IRRI), Filipina. Wereng hijau (N. virescens) yang digunakan sebagai agens penularan diperoleh dengan menangkapnya di daerah Bogor (Jawa Barat). Benih padi kultivar TN1 dan FK135 ditabur dalam cawan petri yang berisi air selama 1 malam. Benih tersebut kemudian ditabur pada tanah di dalam pot. Tanaman padi dipelihara dalam rumah kaca yang bebas dari serangga. Tanaman berumur 5-6 hari digunakan untuk inokulasi virus menggunakan metode test tube (Azzam et al. 2000). Setiap bibit tanaman padi diferensial diletakkan dalam tabung (18 $\mathrm{mm} \times 150 \mathrm{~mm}$ ) yang berisi $0.5 \mathrm{~cm}$ air, lalu ke dalam tabung dimasukan sebanyak 3 wereng hijau dewasa yang telah diakuisisi selama 4 hari pada tanaman sumber inokulum virus. Wereng hijau dibiarkan makan pada tanaman padi diferensial selama sehari semalam, selanjutnya tanaman padi dipindah dalam pot. Masing-masing kultivar padi diferensial disusun berdasarkan pada rancangan acak kelompok. Sebagai perlakuan ialah asal isolat, yaitu Bali (Denpasar), Kalimantan Selatan (Tanah Laut), Sulawesi Selatan (Lanrang), Jawa Barat-1 (Subang), Jawa Tengah (Solo), Jawa Timur (Jember), Nusa Tenggara Barat (Mataram), dan Jawa Barat-2 (Bogor). Masing-masing perlakuan diulang sebanyak 3 pot dengan masing-masing pot berisi 3 tanaman. Tanaman padi dipelihara dan dirawat sesuai standar agronomi.

Pengamatan dilakukan terhadap tinggi tanaman, jumlah anakan, persentase tanaman terserang, dan gejala yang ditimbulkan. Pengamatan tersebut dilakukan pada saat tanaman berumur 4 minggu setelah inokulasi. Indeks penyakit (IP) dihitung mengikuti standar evaluation system (SES) IRRI untuk padi (IRRI 1996):

$$
\mathrm{IP}=\frac{n(3)+n(5)+n(7)+n(9)}{t n}, \text { dengan }
$$

$n(3), n(5), n(7)$, dan $n(9)$ adalah jumlah tanaman yang menunjukkan reaksi pada skala $3,5,7$, dan 9 ; tn adalah jumlah total tanaman yang diskor.

Skala 1, tanpa gejala; $3,1-10 \%$ berkurang tingginya, diskolorasi daun kuning sampai kuning-oranye yang tidak jelas; 5, 11-30\% berkurang tingginya, diskolorasi daun kuning sampai kuning-oranye yang tidak jelas; 7, 31-50\% berkurang tingginya, dengan diskolorasi daun kuning sampai kuning-oranye yang jelas; 9, lebih dari 50\% berkurang tingginya, dengan diskolorasi daun kuning sampai kuning-oranye yang jelas.

Respons ketahanan tanaman selanjutnya digolongkan berdasarkan pada hasil penghitungan indeks penyakit, yaitu tahan $(\mathrm{T})$, dengan IP 0-3; moderat (M), dengan IP 4-6; dan rentan (R), dengan IP 7-9. Perbedaan respons tanaman tersebut digunakan untuk menentukan virulensi masing-masing isolat virus. Indeks penyakit yang rendah berarti bahwa tanaman padi memiliki penurunan tinggi tanaman yang relatif lebih rendah (agak kerdil) dan keparahan penyakit yang ringan demikian sebaliknya untuk indeks penyakit yang tinggi. Indeks penyakit yang tinggi menunjukkan tingginya virulensi virus yang menginfeksi. 
Analisis ragam dilakukan dengan menggunakan uji $\mathrm{F}$, dan jika terdapat perbedaan di antara perlakuan dilanjutkan dengan uji jarak berganda Duncan pada $\alpha 0.05$ dengan menggunakan program Statistical Analysis System 6.12.

\section{HASIL}

Hasil uji pada kultivar padi diferensial menunjukkan bahwa terdapat perbedaan respons tanaman TN1 dan FK135 terhadap beberapa isolat RTV. Pengamatan terhadap masa inkubasi menunjukkan bahwa isolat Jawa Barat-1 mampu menyebabkan munculnya gejala yang paling cepat pada kedua kultivar padi diferensial, sedangkan isolat Bali, Jawa Tengah, Nusa Tenggara Barat, dan Jawa Timur menyebabkan munculnya gejala relatif lebih lambat (Tabel 1). Semua tanaman padi kultivar TN1 yang diinokulasi dengan isolatisolat RTV dapat terinfeksi (kejadian penyakit 100\%), sedangkan pada kultivar FK135 kejadian penyakit tungro oleh isolat RTV Jawa Tengah dan Nusa Tenggara Barat lebih rendah dibandingkan isolat lainnya (77.78\%). Kedua isolat tersebut diduga mempunyai virulensi yang relatif lebih rendah dibandingkan dengan isolat virus tungro lainnya.

Gejala penyakit yang disebabkan oleh infeksi RTV juga bervariasi baik pada kultivar padi TN1 maupun FK135. Perbedaan gejala terutama adalah pada tingkat perubahan warna daun (Tabel 2). Pada tanaman padi TN1 tingkat keparahan penyakit ditunjukkan oleh warna daun yang menjadi oranye, sedangkan pada tanaman padi FK135 ditunjukkan oleh gejala bergaris dengan warna kuning sampai oranye. Berdasarkan pada variasi gejala tersebut, terutama pada kultivar padi FK135, isolat RTV dapat dibedakan menjadi 3 kelompok. Kelompok penyebab gejala bergaris oranye di antara tulang daun oleh isolat RTV Jawa Barat-1, dan RTV Jawa Barat-2; (2) RTV Jawa Timur penyebab gejala bergaris kuning; (3) RTV Bali, Kalimantan Selatan, Sulawesi Selatan, Jawa Tengah, dan Nusa Tenggara Barat penyebab gejala bergaris putih-kekuningan. Selain perbedaan tingkat perubahan warna daun, respons tanaman terhadap infeksi tungro juga ditunjukkan oleh penurunan yang nyata pada tinggi tanaman dan jumlah anakan pada kultivar TN1 dan FK135 (Tabel 3).

Hasil penghitungan kejadian penyakit sangat berhubungan dengan hasil penghitungan indeks penyakit. Pada kultivar FK135, kejadian penyakit tungro oleh isolat RTV Jawa Tengah dan Nusa Tenggara Barat lebih rendah daripada isolat lainnya. Isolat RTV Jawa Tengah dan RTV Nusa Tenggara Barat ternyata juga menyebabkan indeks penyakit

Tabel 1 Masa inkubasi dan kejadian penyakit (KP) pada dua kultivar padi 4 minggu setelah inokulasi dengan 8 isolat Rice tungro virus (RTV)

\begin{tabular}{lccccc}
\hline & \multicolumn{2}{c}{ Kultivar TN1 } & & \multicolumn{2}{c}{ Kultivar FK135 } \\
\cline { 2 - 3 } \cline { 5 - 6 } Isolat RTV asal & $\begin{array}{c}\text { Masa inkubasi } \\
\text { (hari) }\end{array}$ & KP $(\%)$ & & $\begin{array}{c}\text { Masa inkubasi } \\
\text { (hari) }\end{array}$ & KP (\%) \\
\hline Kontrol & - & $0 \mathrm{~b}$ & & - & $0 \mathrm{c}$ \\
Bali & $11-26$ & $100 \mathrm{a}$ & & $12-27$ & $100 \mathrm{a}$ \\
Kalimantan Selatan & $11-23$ & $100 \mathrm{a}$ & & $11-21$ & $100 \mathrm{a}$ \\
Sulawesi Selatan & $11-20$ & $100 \mathrm{a}$ & & $11-26$ & $100 \mathrm{a}$ \\
Jawa Barat-1 & $10-21$ & $100 \mathrm{a}$ & & $11-16$ & $100 \mathrm{a}$ \\
Jawa Tengah & $12-25$ & $100 \mathrm{a}$ & & $11-28$ & $78 \mathrm{~b}$ \\
Jawa Timur & $12-22$ & $100 \mathrm{a}$ & & $11-26$ & $100 \mathrm{a}$ \\
Nusa Tenggara Barat & $13-23$ & $100 \mathrm{a}$ & & $11-27$ & $78 \mathrm{~b}$ \\
Jawa Barat-2 & $11-23$ & $100 \mathrm{a}$ & & $11-20$ & $100 \mathrm{a}$
\end{tabular}

Angka yang diikuti oleh huruf yang sama pada kolom yang sama tidak berbeda nyata berdasarkan uji jarak berganda Duncan pada taraf nyata $5 \%$. 
Tabel 2 Gejala penyakit tungro pada dua kultivar padi 4 minggu setelah inokulasi dengan 8 isolat Rice tungro virus (RTV)

\begin{tabular}{|c|c|c|}
\hline \multirow{2}{*}{$\begin{array}{l}\text { Isolat RTV } \\
\text { asal }\end{array}$} & \multicolumn{2}{|c|}{ Gejala penyakit } \\
\hline & Kultivar TN1 & Kultivar FK135 \\
\hline Kontrol & Tumbuh normal dengan daun hijau & Tumbuh normal dengan daun hijau \\
\hline Bali & $\begin{array}{l}\text { Agak kerdil, perubahan warna daun } \\
\text { kuning-oranye }\end{array}$ & $\begin{array}{l}\text { Agak kerdil, daun bergejala garis putih } \\
\text { di antara tulang daun }\end{array}$ \\
\hline $\begin{array}{l}\text { Kalimantan } \\
\text { Selatan }\end{array}$ & $\begin{array}{l}\text { Kerdil, perubahan warna daun kuning } \\
\text { sampai oranye }\end{array}$ & $\begin{array}{l}\text { Agak kerdil, daun bergejala garis putih } \\
\text { di antara tulang daun }\end{array}$ \\
\hline Sulawesi & Sangat kerdil, perubahan warna daun & Agak kerdil, daun bergejala garis putih \\
\hline Selatan & oranye & kekuningan di antara tulang daun \\
\hline Jawa Barat-1 & $\begin{array}{l}\text { Sangat kerdil, perubahan warna daun } \\
\text { oranye }\end{array}$ & $\begin{array}{l}\text { Sangat kerdil, daun bergejala garis } \\
\text { oranye di antara tulang daun }\end{array}$ \\
\hline Jawa Tengah & $\begin{array}{l}\text { Agak kerdil, diskolorasi daun kuning- } \\
\text { oranye }\end{array}$ & $\begin{array}{l}\text { Agak kerdil, daun bergejala garis putih } \\
\text { kekuningan di antara tulang daun }\end{array}$ \\
\hline Jawa Timur & $\begin{array}{l}\text { Agak kerdil, perubahan warna daun } \\
\text { kuning-oranye }\end{array}$ & $\begin{array}{l}\text { Kerdil, daun bergejala garis kuning di } \\
\text { antara tulang daun }\end{array}$ \\
\hline $\begin{array}{l}\text { Nusa Tenggara } \\
\text { Barat }\end{array}$ & $\begin{array}{l}\text { Sangat kerdil, perubahan warna daun } \\
\text { oranye }\end{array}$ & $\begin{array}{l}\text { Agak kerdil, daun bergejala garis putih } \\
\text { di antara tulang daun }\end{array}$ \\
\hline Jawa Barat-2 & $\begin{array}{l}\text { Sangat kerdil, perubahan warna daun } \\
\text { oranye }\end{array}$ & $\begin{array}{l}\text { Kerdil, daun bergejala garis oranye di } \\
\text { antara tulang daun }\end{array}$ \\
\hline
\end{tabular}

Tabel 3 Tinggi tanaman dan jumlah anakan dua kultivar padi 4 minggu setelah inokulasi dengan 8 isolat Rice tungro virus (RTV)

\begin{tabular}{|c|c|c|c|c|}
\hline \multirow[b]{2}{*}{ Isolat RTV asal } & \multicolumn{2}{|c|}{ Kultivar TN1 } & \multicolumn{2}{|c|}{ Kultivar FK135 } \\
\hline & $\begin{array}{l}\text { Tinggi tanaman } \\
\qquad(\mathrm{cm})\end{array}$ & $\begin{array}{l}\text { Jumlah } \\
\text { anakan }\end{array}$ & $\begin{array}{l}\text { Tinggi tanaman } \\
\text { (cm) }\end{array}$ & $\begin{array}{l}\text { Jumlah } \\
\text { anakan }\end{array}$ \\
\hline Kontrol & $60.17 \mathrm{a}$ & $2.89 \mathrm{a}$ & $65.61 \mathrm{a}$ & $2.76 \mathrm{a}$ \\
\hline Bali & $38.67 \mathrm{~b}$ & $1.56 \mathrm{bc}$ & $45.61 \mathrm{bc}$ & $1.67 \mathrm{bc}$ \\
\hline Kalimantan Selatan & $33.57 \mathrm{c}$ & $1.33 \mathrm{bc}$ & $40.89 \mathrm{~cd}$ & $2.00 \mathrm{~b}$ \\
\hline Sulawesi Selatan & $28.78 \mathrm{~cd}$ & $1.67 \mathrm{bc}$ & $40.95 \mathrm{~cd}$ & $1.45 \mathrm{bc}$ \\
\hline Jawa Barat-1 & $30.83 \mathrm{~cd}$ & $1.11 \mathrm{c}$ & $27.67 \mathrm{e}$ & $1.00 \mathrm{c}$ \\
\hline Jawa Tengah & $39.05 \mathrm{~b}$ & $1.78 \mathrm{~b}$ & $51.28 \mathrm{~b}$ & $2.00 \mathrm{~b}$ \\
\hline Jawa Timur & $40.39 \mathrm{~b}$ & $1.78 \mathrm{~b}$ & $37.56 \mathrm{~d}$ & $1.33 \mathrm{bc}$ \\
\hline Nusa Tenggara Barat & $28.47 \mathrm{~d}$ & $1.67 \mathrm{bc}$ & $47.17 \mathrm{bc}$ & $2.00 \mathrm{~b}$ \\
\hline Jawa Barat-2 & $28.33 \mathrm{~d}$ & $1.22 \mathrm{bc}$ & $37.44 \mathrm{~d}$ & $1.33 \mathrm{bc}$ \\
\hline
\end{tabular}

Angka yang diikuti oleh huruf yang sama pada kolom yang sama tidak berbeda nyata berdasarkan uji jarak berganda Duncan pada taraf nyata $5 \%$.

yang lebih rendah pada kultivar FK135. Indeks penyakit tertinggi dicapai pada inokulasi dengan isolat RTV Jawa Barat-1 pada kedua kultivar padi (Tabel 4). Isolat RTV Jawa Barat-1 menyebabkan keparahan tertinggi, berarti isolat tersebut mempunyai virulensi paling tinggi dibandingkan dengan isolat virus tungro yang lain. Adanya variasi keparahan penyakit pada setiap kultivar padi ini menunjukkan adanya variasi virulensi isolat virus.
Kultivar TN1 dan FK135 menunjukkan respons ketahanan yang berbeda-beda ketika diinokulasi dengan isolat RTV yang berbeda. Meskipun semua isolat menyebabkan kejadian penyakit sebesar $100 \%$ pada kultivar TN1 dan 100\% pada kultivar FK135 - kecuali isolat Jawa Tengah dan Nusa Tenggara Barat-, tetapi keparahan penyakitnya berbeda. Hal ini ditunjukkan oleh tingkat indeks penyakit yang dihitung dari hasil skoring penyakit 
berdasarkan pada persentase penurunan tinggi tanaman dan tingkat diskolorasi daun. Dari hasil penghitungan indeks penyakit, virulensi masing-masing isolat RTV dapat dikelompokkan menjadi 4 golongan berdasarkan pada respons ketahanan kedua kultivar diferensial tersebut, yaitu $\mathrm{R}$ dan $\mathrm{R}, \mathrm{R}$ dan $\mathrm{M}$, $\mathrm{M}$ dan $\mathrm{R}$, dan $\mathrm{M}$ dan $\mathrm{M}$, berturut-turut pada kultivar TN1 dan FK135. Respon ketahanan $\mathrm{R}, \mathrm{M}$, dan T ialah masing-masing untuk rentan, moderat dan tahan (Tabel 5).

Hasil penelitian ini menunjukkan bahwa tingkat virulensi tertinggi sampai terendah berturut-turut ialah RTV Jawa Barat-1, RTV Jawa Barat-2, RTV Jawa Timur, RTV Kalimantan Selatan, RTV Sulawesi Selatan, RTV Nusa Tenggara Barat, RTV Bali, dan RTV Jawa Tengah. Dari hasil tersebut dapat dikatakan bahwa isolat RTV Jawa Barat-1 dan Jawa Barat-2 mempunyai virulensi paling tinggi karena mampu menyebabkan respons rentan pada kedua kultivar, tingkat virulensi moderat adalah isolat RTV Jawa Timur, Kalimantan Selatan, Sulawesi Selatan dan Nusa Tenggara Barat karena hanya mampu menyebabkan respons rentan pada salah satu kultivar dan moderat pada kultivar yang lain. Isolat Jawa Timur lebih virulen pada kultivar padi FK135, sedangkan isolat Kalimantan Selatan, Sulawesi Selatan dan Nusa Tenggara Barat lebih virulen pada kultivar padi TN1. Virulensi yang paling rendah ditunjukkan oleh isolat RTV dari Bali dan Jawa Tengah yang hanya menyebabkan respons moderat pada kedua kultivar.

Tabel 4 Indeks penyakit pada dua kultivar padi 4 minggu setelah inokulasi dengan 8 isolat Rice tungro virus (RTV)

\begin{tabular}{lcc}
\hline \multirow{2}{*}{ Isolat RTV asal } & \multicolumn{2}{c}{ Indeks penyakit } \\
\cline { 2 - 3 } & Kultivar TN1 & Kultivar FK135 \\
\hline Kontrol & $0.00 \mathrm{c}$ & $0.00 \mathrm{e}$ \\
Bali & $6.11 \mathrm{~b}$ & $5.45 \mathrm{~cd}$ \\
Kalimantan Selatan & $7.44 \mathrm{a}$ & $6.33 \mathrm{bc}$ \\
Sulawesi Selatan & $7.89 \mathrm{a}$ & $6.33 \mathrm{bc}$ \\
Jawa Barat-1 & $8.55 \mathrm{a}$ & $8.78 \mathrm{a}$ \\
Jawa Tengah & $6.11 \mathrm{~b}$ & $4.33 \mathrm{~d}$ \\
Jawa Timur & $5.89 \mathrm{~b}$ & $7.22 \mathrm{~b}$ \\
Nusa Tenggara Barat & $8.11 \mathrm{a}$ & $5.00 \mathrm{~d}$ \\
Jawa Barat-2 & $8.11 \mathrm{a}$ & $7.45 \mathrm{~b}$ \\
\hline
\end{tabular}

Angka yang diikuti oleh huruf yang sama pada kolom yang sama tidak berbeda nyata berdasarkan uji jarak berganda Duncan pada taraf nyata 5\%.

Tabel 5 Respons ketahanan dua kultivar padi 4 minggu setelah inokulasi dengan 8 isolat Rice tungro virus (RTV)

\begin{tabular}{lcc}
\hline \multirow{2}{*}{ Isolat RTV asal } & \multicolumn{2}{c}{ Indeks penyakit } \\
\cline { 2 - 3 } & Kultivar TN1 & Kultivar FK135 \\
\hline Kontrol & - & - \\
Bali & $\mathrm{M}$ & $\mathrm{M}$ \\
Kalimantan Selatan & $\mathrm{R}$ & $\mathrm{M}$ \\
Sulawesi Selatan & $\mathrm{R}$ & $\mathrm{M}$ \\
Jawa Barat-1 & $\mathrm{R}$ & $\mathrm{R}$ \\
Jawa Tengah & $\mathrm{M}$ & $\mathrm{M}$ \\
Jawa Timur & $\mathrm{M}$ & $\mathrm{R}$ \\
Nusa Tenggara Barat & $\mathrm{R}$ & $\mathrm{M}$ \\
Jawa Barat-2 & $\mathrm{R}$ & $\mathrm{R}$ \\
\hline
\end{tabular}

T, tahan (IP= 0-3); M, moderat Tahan ( $\mathrm{IP}=4-6) ; \mathrm{R}$, rentan (IP= 7-9) . 


\section{PEMBAHASAN}

Pengujian tingkat virulensi RTV dapat dilakukan menggunakan kultivar diferensial, seperti yang dilakukan Cabauatan et al. (1995) yang membedakan galur RTV di Filipina dengan kultivar padi FK 135 dan TN1. Mereka melaporkan ada empat galur virus tungro, yaitu L, G1, G2, dan Ic. Galur G1 dan Ic dapat dibedakan oleh reaksi kultivar FK135, sedangkan G1 dan G2 dapat dibedakan oleh TN1. Galur Ic menyebabkan kerdil yang parah, anakan berkurang, daun menyempit, dan klorosis interveinal helaian daun (striping dan/atau mottling) yang jelas pada kultivar FK135, sedangkan G1 dan G2 hanya menyebabkan gejala agak kerdil dan daun tetap hijau normal. Pada kultivar TN1, virus tungro galur G1, dan Ic menyebabkan tanaman agak kerdil, tetapi tidak terjadi perubahan warna daun, sedangkan galur G2 menyebabkan kerdil yang parah dan daun menjadi kuning sampai oranye mirip yang disebabkan oleh galur L.

Pengamatan terhadap masa inkubasi menunjukkan bahwa kecepatan munculnya gejala untuk masing-masing isolat dapat berbedabeda. Patogenisitas virus bergantung pada keagresifan atau keinfektifan dan tingkat virulensi virus tersebut (Bos 1994). Perbedaan gejala yang muncul ialah terutama pada tingkat perubahan warna daun. Pada tanaman padi TN1 tingkat keparahan penyakit ditunjukkan oleh warna daun yang menjadi oranye, sedangkan pada tanaman padi FK135 ditunjukkan oleh gejala bergaris dengan warna kuning sampai oranye. Cabauatan et al. (1995) membedakan galur RTBV berdasarkan pada keparahan gejala pada kultivar TN1 dan keberadaan klorosis interveinal berupa garis dan/atau belang pada kultivar FK135. Pada penelitian ini tidak ditemukan gejala belang pada daun. Srinivasulu dan Jeyarajan (1990) menjelaskan bahwa adanya perbedaan gejala klorosis dan warna kuning-oranye daun padi terinfeksi virus tungro ialah karena kandungan pigmen hijau (klorofil), pigmen oranye (karoten), dan pigmen kuning (santofil) yang berbeda pada fase tingkat patogenesis.
Hasil pengujian virulensi RTV ini relevan dengan hasil penelitian Hasanuddin dan Widiarta (2006). Hasil penelitian menggunakan beberapa kultivar padi tahan yang sudah dilepas menunjukkan bahwa inokulum RTV Jawa Barat mempunyai virulensi yang paling tinggi dibandingkan dengan RTV Bali, Jawa Tengah, dan Jawa Timur. Isolat RTV Bali mempunyai virulensi yang hampir sama dengan RTV Jawa Timur. Suprihanto (2009) melaporkan hasil pengujian dengan menggunakan varietas diferensial TN1 dan FK135 isolat RTV Temanggung (Jawa Tengah), Kuningan (Jawa Barat), dan Magelang (Jawa Tengah) mempunyai virulensi yang lebih tinggi dibandingkan dengan RTV Lanrang (Sulawesi Selatan). Dengan menggunakan lima varietas tahan tungro yang sudah dilepas (Tukad Petanu, Tukad Balian, Tukad Unda, Bondoyudo, Kalimas), dan satu kultivar rentan TN1. Suprihanto et al. (2010) melaporkan hasil yang sama dengan hasil uji menggunakan kultivar diferensial FK135 dan TN1. Isolat RTV Temanggung (Jawa Tengah), Kuningan (Jawa Barat), dan Magelang (Jawa Tengah) mempunyai virulensi yang lebih tinggi dibandingkan dengan RTV Lanrang (Sulawesi Selatan). Adanya perbedaan tersebut dapat disimpulkan bahwa isolat RTV Jawa Tengah yang digunakan dalam penelitian tersebut adalah RTV Magelang dan Temanggung. Dalam penelitian ini digunakan isolat RTV dari Solo sehingga mempunyai virulensi yang lebih rendah dari isolat Sulawesi Selatan (Lanrang). Pada satu daerah yang sama dalam lokasi yang berbeda memungkinkan adanya variasi virulensi. Variasi ini dapat terjadi oleh beberapa faktor, seperti lingkungan, dominasi tanaman inang, dan serangga vektor. Dalam suatu populasi virus selalu terdapat variasi. Hanya individu virus yang tahan terhadap tekanan lingkungan, dominasi tanaman inang tahan, dan dapat berinteraksi secara baik dengan serangga vektor yang berkembang pada daerah tersebut, adalah virus yang akan bertahan dan berkembang menjadi dominan pada daerah tersebut (Garcia-Arenal et al. 2001; Azzam dan Chancellor 2002). 
Berdasarkan pada respons tanaman diferensial-terutama yang ditunjukkan oleh tingkat keparahan gejala penyakit berupa tingkat kekerdilan, dan diskolorasi daun pada TN1, tingkat kekerdilan dan keberadaan klorosis interveinal pada FK 135-maka dapat disimpulkan bahwa tingkat virulensi isolat RTV dari beberapa daerah endemis penyakit tungro di Indonesia dapat dikelompokkan menjadi 3 tingkat. Virulensi paling tinggi adalah isolat RTV dari Jawa Barat; tingkat virulensi moderat adalah isolat RTV dari Jawa Timur, Kalimantan Selatan, Sulawesi Selatan, dan Nusa Tenggara Barat; tingkat virulensi rendah ditunjukkan oleh isolat RTV dari Bali dan Jawa Tengah. Namun demikian, tingkat virulensi RTV tersebut tidak dipengaruhi oleh batas wilayah administratif daerah melainkan dipengaruhi oleh kondisi lingkungan yang menyebabkan terjadinya perkembangan virulensi RTV. Informasi tentang variasi virulensi RTV ini diharapkan dapat membantu pemetaan virulensi tungro di daerah endemis penyakit tungro di Indonesia sebagai dasar dalam pengendalian terutama penggunaan varietas padi tahan tungro.

\section{UCAPAN TERIMA KASIH}

Penelitian ini merupakan bagian dari tesis yang dibiayai oleh proyek PAATP Badan Litbang Pertanian. Ucapan terima kasih disampaikan kepada I Nyoman Widiarta, di Balai Besar Penelitian Tanaman Padi yang telah membantu dalam koleksi isolat dan memberikan masukan dalam penelitian ini.

\section{DAFTAR PUSTAKA}

Angeles ER, Cabunagan RC, Tabien RE, and Khush GS. 2008. Resistance to tungro vectors and viruses. Di dalam: Tiongco ER, Angeles ER. and Sebastian LS, editor. Rice tungro virus disease: a paradigm in disease management. Nueva Ecija (PH): Philippine Rice Research Institute and Honda Research Institute Japan Co. Ltd. hlm 117-141.
Azzam O, Cabunagan RC, Chancellor T. 2000. Methods for Evaluating Resistance to Rice Tungro Disease. IRRI Discussion Paper Series No.38. Manila (PH): International Rice Research Institute.

Azzam O, Chancellor TCB. 2002. The biology, epidemiology, and management of rice tungro disease in Asia. Plant Dis. 86(2):88-100. DOI: http://dx.doi. org/10.1094/PDIS.2002.86.2.88.

Bos L. 1994. Pengantar Virologi Tumbuhan. Triharso, penerjemah. Yogyakarta (IN): Gadjah Mada University Pr. Terjemahan dari: Introduction to Plant Virology.

Burhanuddin, Widiarta IN, dan Hasanuddin A. 2006. Penyempurnaan pengendalian terpadu penyakit tungro dengan strategi menghindari infeksi dan pergiliran varietas tahan. J HPT Tropik. 6(2):92-99.

Cabauatan PQ, Cabunagan RC, Koganezawa H. 1995. Biological variants of rice tungro virusses in the Philippines. Phytopathology. 85(1):77-81. DOI: http:// dx.doi.org/10.1094/Phyto-85-77.

Garcia-Arenal F, Fraile A, Malpica JM. 2001. Variability and genetic structure of plant virus populations. Ann Rev phytopathol. 39:157-186.DOI:http://dx.doi.org/10.1146/ annurev.phyto.39.1.157.

Hasanuddin A, Widiarta IN. 2006. Variation in virulence of virus inoculums to tungro resistant rice varieties in Indonesia. Di dalam: Rice Industry, Culture, and Environment. Book 1. Proceedings of Internationl Rice Conference; 2005 Sep 12-14; Bali (ID): Indonesian Agency for Agricultural Research and Development dan International Rice Research Institute. hlm 301-307.

Hibino H, Roechan M, Sudarisman S. 1978. Association of two types of virus particles with penyakit habang (tungro disease) of rice in Indonesia. Phytopathology. 68: 1412-1416.DOI: http://dx.doi.org/10.1094/ Phyto-68-1412.

[IRRI] International Rice Research Institute. 1996. Standard Evaluation System for Rice. Ed ke-4. Manila (PH): INGER Genetic Resources Center. 
Pakki S, Bastian A, Suhartati. 2010. Sebaran penyakit tungro di sentra prooduksi padi di Indonesia timur. Di dalam: Prosiding Seminar Ilmiah dan Pertemuan Tahunan PEI dan PFI XX Komisariat Daerah Sulawesi Selatan; 2010 Mei 27; Makassar (ID): PEI dan PFI Komda Sulawesi Selatan. hlm. 139-151.

Raga IN. 2008. Perkembangan dan penyebaran penyakit tungro di Indonesia. Di dalam: Prosiding Seminar Nasional Strategi Pengendalian Penyakit Tungro Mendukung Peningkatan Produksi Beras; 2008 Sep 5-6; Makassar (ID): Pusat Penelitian dan Pengembangan Tanaman Pangan, Badan Penelitian dan Pengembangan Pertanian. hlm 1-9.

Sama S, Hasanuddin A, Manwan I, Cabunagan RC, Hibino H. 1991. Integrated rice tungro disease management in South Sulawesi, Indonesia. Crop Protection. 10(1):3440. DOI: http://dx.doi.org/10.1016/02612194(91)90022-J.

Srinivasulu B, Jeyarajan R. 1990. Change in rice leaf pigment due to tungro (RTV) infection. IRRN. 15(3):13.

Suprihanto, Yasin M. 2009. Variasi biologis virus tungro dari daerah Kuningan, Magelang, Temanggung, dan Lanrang. Di dalam: Inovasi Teknologi Padi
Mengantisipasi Perubahan Iklim Global Mendukung Ketahanan Pangan. Prosiding Seminar Nasional Padi (Buku 1); 2008 23-24 Jul; Sukamandi (ID): Balai Besar Penelitian Tanaman Padi. hlm 463-469.

Suprihanto, Widiarta IN, dan Kusdiaman D. 2010. Evaluasi virulensi virus tungro dari beberapa daerah endemi dan uji ketahanan plasma nutfah padi. J Perlintan Ind. 16(1): 33-41.

Widiarta IN. 1999. The role of vector control in tungro management. Di dalam: Chancellor TCB, Azzam O, Heong KL, editor. Rice Tungro Disease Management. Los Banos (PH): International Rice Research Institute. hlm 143-150.

Widiarta IN, Daradjat AA. 2000. Daya tular tungro daerah endemis terhadap varietas tahan. Berita Puslitbangtan. 18:1-2.

Widiarta IN, Kusdiaman D, Suprihanto 2008. Variasi dan mekanisme perubahan infektivitas inokulum tungro. Di dalam: Prosiding Seminar Nasional Strategi Pengendalian Penyakit Tungro Mendukung Peningkatan Produksi Beras; 2008 Sep 5-6; Makassar (ID): Pusat Penelitian dan Pengembangan Tanaman Pangan, Badan Penelitian dan Pengembangan Pertanian. hlm 10-21. 